\title{
Analýza změn odtokových poměrů pro Ceskou republiku
}

\section{LUKÁŠ SMELÍK}

Klíčová slova: srážky - CN křivky - odtok - eroze - protierozní opatření - protipovodňová opatření

\section{SOUHRN}

Dílčím cílem projektu "Strategie ochrany před negativními dopady povodní a erozními jevy prírodě blízkými opatřeními v České republice" bylo zjištění současných odtokových poměrů v České republice pomocí metody CN křivek. V plochách vybraných povodí, kde podle výpočtu vychází velké odtokové výšky a malá vsakovací schopnost, byla v ideové rovině navržena typizovaná protierozní (PEO) a protipovodňová (PPO) opatření, která se podle dřivějších zkušeností jeví jako účinná, ekonomicky únosná a prosaditelná. Efekt těchto navrhovaných opatření [1] byl na celém území České republiky posouzen pomocí výpočtu odtokových poměrů metodou CN křivek. Z rozdílů odtokových poměrů současného stavu území a území s návrhy byla analyzována účinnost opatření na diskretizovaném území - povodích IV. rádu. Analýzy proběhly $\checkmark$ prostředí GIS.

\section{ÚVOD}

Česká republika byla v posledních letech zasažena několika povodněmi z př́ivalových srážek, které urychlily prosazování změn odtokových poměrů v jednotlivých územích s cílem zvýšit ochranu před negativními dopady eroze a před lokálními povodněmi zejména v obcích. Obecně má výzkum v této oblasti poukázat na povodí ohrožená a nedostatečně chráněná před erozí půdy a s tím související zvýšený povrchový odtok. Navrhovaná ideová opatření [1] v ploše povodí jsou souborem doporučených opatření, která mají omezit negativní dopady př́valových srážek. Pozitivním prínosem návrhů je rovněž zachování kvalitní půdy na obhospodařovaných pozemcích.

Odtokové poměry (odtokový režim) jsou souborem prírodních a umělých (antropogenně ovlivněných) podmínek, které ovlivňují povrchový a podpovrchový odtok z povodí. Protože nelze postihnout veškeré jevy v povodí a ve vodních tocích, jsou nejdůležitější z jevů schematizovány. Hlavní ovlivňující podmínky, zejména průběh srážkové události, typ pokryvu a vlastnosti půd, mohou působit bud’ v celém povodí, nebo jen v jeho části. K př́mému odtoku dochází ve chvíli, kdy je půda nasycena predchozími srážkami, nebo v průběhu př́valových srážek, kdy se voda nestačí vsakovat. Čím je déšt̉ intenzivnější, tj. spadne velký srážkový úhrn za krátký časový úsek, tím je odtok vyšší. Voda, která se $\checkmark$ povodí nevsákne nebo neakumuluje $v$ nádržích či snížených místech, je nazývána povrchový odtok. Vztahuje se k uzávěrovému profilu, což je nejniže položené místo v povodí, kterým voda odtéká. Tímto místem může být profil povodí IV. rádu, přispívající plocha kritického bodu nebo povodí k profilu hráze navrženého akumulačního prostoru. Velikost projevu povrchového odtoku Ize pozorovat v korytech vodních toků, kanálech, údolnicích nebo nádržích jako zvýšení úrovně vodní hladiny.
V rámci řešení projektu Strategie ochrany před negativními dopady povodní a erozními jevy prírodě blízkými opatřeními v České republice (dále jen Strategie) byly sledovány prínosy opatření pomocí změn hodnot prímého odtoku. Za tímto účelem bylo nezbytné stanovit velikost přímého odtoku před a po návrzích vhodných opatření a analyzovat vzniklé rozdíly výšek a objemů odtoku. $\vee$ prípadě dílčích hydrologických celků, kde byly dosaženy vysoké rozdíly $v$ hodnotách prímého odtoku, se doporučuje realizace opatření se všemi prínosy, tj. zvýšením vsaku deštové vody do pưdy a zpomalení nebo zadržení odtékající vody.

\section{METODY VÝPOČTU PŘÍMÉHO ODTOKU}

\section{Použivané metody}

Odtok z povodí se stanovuje na základě četných srážkoodtokových matematických modelů, které popisují vztahy v řešeném povodí a predikují velikost odtoku na základě vstupních údajů o srážkách. Modely se liší mírou schematizace povodí, množstvím vstupních údajů, náročností na výpočet a shodou $s$ reálně naměřenými parametry. Některé modely jsou vhodné pro určitý typ povodí a mají tak omezenou použitelnost. Jak uvádí [2], použití konvenčních metod měření odtoku je velmi nákladné, časově náročné a náchylné k chybám z důvodu nedostatku spolehlivých podkladových dat. Většina povodí má navíc omezený počet měřidel pro záznam srážek a množství odtoku. Z existujících prístupů pro odhad odtoku z povodí bylo vybráno několik z nich [2, 3]:

- model povodí UBCWM: model detailně popisuje hydrologii horských a zaledněných oblastí; pro výpočet odtoku v prostředí České republiky není svým zaměřením vhodný;

— umělé neuronové sítě ANN (Artificial Neural Network): jsou vhodné spíše pro malá povodí, nebot je řeší detailně na základě souvislostí mezi mnoha srážkovými událostmi; pro rešení na území celé ČR nejsou neuronové sítě vhodné;

- metoda čísel odtokových křivek SCS-CN: metoda vybraná pro řešení odtokových poměrů; je založená na znalosti srážek a půdního pokryvu a jako u jedné z mála Ize vyhodnotit změny v krajině bez dalši kalibrace modelu;

- modely jednotkových hydrogramů: jednotkový hydrogram má stálou intenzitu a rovnoměrné rozložení srážek v povodí; výpočet vychází ze znalosti měřených srážek a odtoků; model je nepoužitelný pro absenci měření ve většině povodí;

— rovnice oblastní: rovnice obsahují koeficienty, které souvisís príslušnostík území nebo k povodí toku; není snadné je automatizovat a navíc jsou výsledky jen orientační; 
— rovnice objemové: rovnice jsou založeny na odhadu povodňové vlny a tvaru hydrogramu; také není snadné je automatizovat a výsledky lze použít jen k orientačním účelům;

- rovnice intenzitní: rovnice byly odvozeny pro srážkové události s krátkou dobou trvání; dosazuje se do nich intenzita srážek podle doby trvání a doby opakování; výpočet není snadné automatizovat a výsledky jsou jen orientační;

- výpočet podle odtokového součinitele: výpočet je jednoduchý, nebot' Ize součinitele najít v tabulkách [4]; z důvodu absence mnohých kombinací druhů povrchů jsou nepoužitelné pro požadované výpočty.

Výpočet stavu odtokových poměrů byl proveden metodou CN křivek, která je z důvodu snadného použití vhodná k řešení v prostředí GIS. Metoda je široce používaná právě pro svou jednoduchost [2]. Pomocí automatizace výpočtů v ArcGIS Ize stanovit výšky a objemy odtoků pro velká území (např. celou Českou republiku), a to během několika výpočtových kroků.

\section{Metoda CN křivek}

Metoda CN křivek (CN z anglického Curve Number) je založena na experimentálním výzkumu. Výpočtové rovnice jsou empirické [4]. Metoda je oblíbená a stále používaná. Používá se ke stanovení velikosti prímého odtoku na základě znalosti intenzity srážek a typu povrchu [5]. Metoda byla testována a ověřena mnohými výzkumy a studiemi odtokových poměrů. $V$ malých povodích existuje dobrá korelace mezi naměřenou výškou odtoku a výškou odtoku stanovenou metodou čísel CN s aplikací GIS. Právě pro tyto důvody byla metoda CN křivek vybrána pro vyjádření odtokových poměrů v projektu Strategie. Podle [6] může být metoda CN křivek použita v navrhování a posuzování technických protierozních opatření, např. pro dráhy soustředěného povrchového odtoku, zatravněné údolnice, průlehy, záchytné prríkopy, zasakovací pásy a malé vodní nádrže. Metodou lze získat informace o prítoku do nádrže, ale vlastní transformace odtoku se řeší zvláštt.

Metoda CN křivek vychází z předpokladu, že poměr mezi aktuální retencí (objem vody zadržený při odtoku) a maximální retencí (potenciálně zadržitelný objem vody) v povodí je stejný jako poměr mezi výškou odtoku a výškou prrivalových srážek po odečtení počátečních ztrát. Výpočet podle Metody čísel odtokových křivek Ize použít pro stanovení objemu přímého odtoku způsobeného návrhovým přivalovým deštěm dané pravděpodobnosti výskytu. Do přímého odtoku se zahrnují dvě složky: povrchový odtok a hypodermický odtok (podpovrchový, tj. proudění v malé vrstvě pod povrchem bez interakce s podzemní vodou).



Obr. 1. Rozčlenění srážkového úhrnu na jednotlivé složky

Fig. 1. Breakdown of rainfall on individual components

\section{Specifika a omezení metody $C N$ křivek}

Metoda byla odvozena na zemědělsky využívaných povodích, jejichž plocha není větší než 10 km² [5]. Zejména pro velká povodí je potřeba u výsledků výpočtů počítat se značnými nepřesnostmi. Správnost volby CN by měla ověřit kalibrace odtoku podle skutečných srážkových událostí. Takové řešení by bylo možné na malém území se známými hydrogramy odtoku. Velká povodí nelze rešit dohromady, a proto je potřeba je rozdělit na dílčí povodí. To souvisí s různým časovým vývojem srážek, odezvou povodí na srážky a rozdílnou dobou odtoku z jednotlivých dílčích povodí. Objemy prímého odtoku z jednotlivých dílčích povodí také nelze jednoduše sčítat. Metoda navíc neuvažuje akumulaci vody v nádržích.

Metoda CN křivek by se měla používat pro části povodí mimo intravilán, ideálně pro volnou krajinu nebo řídce urbanizovaná území [4]. Zejména v urbanizovaném území může dojít k situaci, že je povrch nepropustný a pod ním je propustná půda [7]. Je tedy očekávána vysoká počáteční retence, ke které ve skutečnosti nemusí dojít.

Nevýhodou metody je vysoká citlivost na zvolené hodnoty CN. Rovněž není k dispozici jasný manuál k tomu, jak určit aktuální vlhkostní poměry půdy. K odhadu stavu nasycení půdy lze využít výšku srážek $v$ predchozích dnech $s$ rozlišením, zda se jedná o vegetační nebo mimovegetační období. $\vee$ modelu pro výpočet se nevyužívá sklon povrchu povodí [2]. Důvodem je fakt, že v USA, kde metoda vznikla, mají pozemky většinou sklony menší než $5 \%$. Proto je použitelnost metody čísel $C N$ v horských povodích omezená. Přes svá omezení je ale stále hojně použivána.

Pro modelování odtoků z prívalových srážek se doporučuje používat Metodu čísel odtokových křivek ve standardní formě (hodnota CNII pro střední nasycení půdy) a pro velikost 24hodinových úhrnů srážek Hs $>100 \mathrm{~mm}$. Metodu Ize použít omezeně i pro nižší srážky v rozmezí 40 až 100 mm [8].

\section{VSTUPNÍ DATA}

Vstupními daty pro výpočet byly rastrové vrstvy srážkových úhrnů s dobami opakování 20, 100 a 200 let od ČHMÚ a rastrové vrstvy CNII křivek před a po návrzích opatření vytvořených $v$ rámci projektu Strategie. Výpočet proběhl v programu ArcGIS pomocí funkce Raster Calculator.

\section{Srážkový úhrn}

Výška srážek Hs (mm) (srážkový úhrn návrhového prívalového deště) je jedním z parametrů, který je potřeba znát pro stanovení odtokových poměrů. Průběh reálné srážky závisí na délce jejího trvání, intenzitě a směru pohybu deště. Srážkový úhrn představuje výšku vrstvy vody, která na konkrétní místo naprší za určitý časový úsek. Výška srážek pro jednotlivé doby opakování se stanovuje z dlouhodobého měření ČHMÚ pomocí statistických analýz. Automatické stanice ČHMÚ měři úhrny srážek v intervalu 10 minut a ty jsou pak dále přepočítávány na hodinové úhrny. Stanice vybavené běžným srážkoměrem měří úhrny za 24 hodin, kdy pozorovatel odečítá hodnoty v 7 hodin ráno následujícího dne. Vzhledem k různé hustotě pokrytí území stanicemi se výška srážek stanovuje plošným váženým průměrem. V rámci řešení projektu Strategie byly jako návrhové zvoleny 24hodinové úhrny srážek s dobou opakování 20, 100 a 200 let. Data o srážkách byla poskytnuta Českým hydrometeorologickým ústavem (ČHMú) pro celé území ČR v rastrové podobě. To bylo výhodné pro řešení v prostředí programu ArcGIS, kde analýzy probíhaly na rastrových datech s danou velikostí pixelu. $\vee$ prípadě dat o srážkách bylo rozlišení jednoho pixelu $1 \mathrm{~km} \times 1 \mathrm{~km}$.

Metoda CN křivek uvažuje s tzv. počáteční ztrátou, která byla stanovena experimentálním výzkumem na 20 \% maximální retence $A$, viz rovnici (4). Tato ztráta 
zahrnuje dešt’ovou vodu zachycenou na rostlinách (intercepce), fyzikálně vyparenou vodu (evaporace), vodu vypařenou dýcháním rostlin (transpirace), vsáknutou vodu (infiltrace) a vodu zachycenou ve snížených místech (povrchová akumulace), viz obr. 1. Výzkum počáteční ztráty vycházel z pozorování reakce prívalových srážek na malých povodích v počátečních fázích deště. V rovnici (3) si Ize všimnout, že maximální potenciální retence je pouze funkcí čísel odtokových křivek CN. Není tedy závislá na srážkách, ale pouze na infiltračních vlastnostech půdy a půdního pokryvu. Lze stanovit výšku srážek, za kterých bude ještě nulový odtok z povodí, a tudíz není potřeba pokračovat ve výpočtu. Nulový odtok bude např. prí $C N=50$ a $\mathrm{Hs}<50 \mathrm{~mm}, \mathrm{CN}=70$ a $\mathrm{Hs}<20 \mathrm{~mm}$ nebo $\mathrm{CN}=90$ a $\mathrm{Hs}<5 \mathrm{~mm}[8]$.

\section{Typ povrchu a způsob jeho využití}

Maximální (potenciální) retenci území $A(\mathrm{~mm})$ potřebnou pro výpočet výšky $H_{0}(\mathrm{~mm})$ a objemu Oph $\left(\mathrm{m}^{3}\right)$ prímého odtoku udávají čísla odtokových křivek CN (-). Čísla CN se podle typu povrchu pohybují mezi hodnotami teoreticky od $C N=0$, kdy se vše vsákne (reálně však od cca $C N=30$ ), do $C N=100$, kdy vše odteče. Hodnota čísel CN závisí na typu povrchu, způsobu jeho využití, prípadném uplatnění protierozních opatření a propustnosti půdy pro vodu.

Typem pokryvu může být les, pole, louka, silnice, zástavba atd. Uvedené typy mohou mít další podtypy, které se liší vegetací, její hustotou a údržbou. Pokryv ovlivňuje, s jakou silou a časovým zpožděním dopadne kapka deště na povrch a jak se bude deštová voda vsakovat. Vsakovací vlastnosti půd se mění v závislosti na aktuálním stavu nasycení z předchozích srážek a prokypření, které závisí např. na zvolené technologii obdělávání. Informace o zemědělských pozemcích byly zjištovány z databáze LPIS (Land Parcel Identification System) [9], cožje geografickýinformační systém evidence využitízemědělské půdy, který byl vytvořen pro účely čerpání dotací vázaných na zemědělskou půdu. Ze systému Ize zjistit druh kultury a údaje o BPEJ (bonitovaná půdně ekologická jednotka), od které se odvíjí produkční schopnost zemědělské půdy (kvalita půdy) a její cena. BPEJ je systém pětimístných číselných kódů, kde číslo na 2. a 3. místě udává hlavní půdní jednotku (HPJ). Pro účely metody CN byly definovány čtyři hydrologické skupiny půd (HSP), které se liší infiltračními charakteristikami (skupina A: rychlost infiltrace $>0,12 \mathrm{~mm} \cdot \mathrm{min}^{-1}$, skupina D: rychlost infiltrace $<0,02 \mathrm{~mm} \cdot \mathrm{min}^{-1}$ ). Tyto hydrologické skupiny je možné v ČR stanovit na základě HPJ [5]. V území, kde není uvedeno využití a BPEJ, Ize rozsah a využití pozemků identifikovat pomocí databáze CORINE Land Cover [10]. Pro vlastní řešení byla k dispozici verze z roku 2012. Podklad sdružuje oblasti stejného typu nebo zobrazuje převládající typ pozemku. Přesnost podkladu je rádově v desítkách metrů.

\section{Stanovení čísel $C N$}

Čísla CN se pro konkrétní pozemky stanovují obvykle podle tabulek. Pro potřeby projektu Strategie byla využívána modifikovaná tabulka 1, která vychází z [5]. Pro vlastní stanovení je potřeba znát druh povrchu a hydrologickou skupinu půd (HSP). Na vodních plochách se hodnoty CN nestanovují. Ke splnění cílů řešení byly vytvořeny dvě rastrové vrstvy čísel odtokových křivek CNII s rozlišením pixelu $10 \mathrm{~m} \times 10 \mathrm{~m}$. Jedna vrstva uvažuje stav současného využití území, druhá vrstva vyjadřuje stav území s návrhovými opatřeními, viz [1]. V každém pixelu je uvedena průměrná hodnota čísel $C N$ stanovená váženým průměrem z typů povrchů a půd v uvedeném pixelu.
Tabulka 1. Hodnoty CNII pro jednotlivé druhy povrchu a hydrologické skupiny půd Table 1. CNII values for individual types of surfaces and hydrological types of soils

\begin{tabular}{lllll}
\multirow{2}{*}{$\begin{array}{l}\text { Současné využití } \\
\text { povrchu }\end{array}$} & HSP & B & C & D \\
\cline { 2 - 5 } & 72 & 81 & 88 & 91 \\
\hline orná půda & 72 & 81 & 88 & 91 \\
\hline chmelnice & 59 & 74 & 82 & 86 \\
\hline vinice & 59 & 74 & 82 & 86 \\
\hline ovocný sad & 49 & 69 & 79 & 84 \\
\hline travní porost & 59 & 74 & 82 & 86 \\
\hline jiná kultura & 45 & 66 & 77 & 83 \\
\hline zalesněno & 36 & 60 & 73 & 79 \\
\hline porost bez rozlišení & 59 & 74 & 82 & 86 \\
\hline ostatní & 59 & 74 & 82 & 86 \\
\hline intravilán & 74 & 84 & 90 & 92 \\
\hline silnice, dálnice & 59 & 74 & 82 & 86 \\
\hline železnice včetně náspu & & & &
\end{tabular}

\section{Předchozí nasycení půdy}

Aktuální vlhkost půdy (nasycení vodou) má vliv na intenzitu vsakování a tím na hodnoty CN. Odtokové křivky se v praxi stanovují pro stavy, kdy je před přivalovými srážkami půda suchá (CNI), středně nasycená (návrhový stav CNII) nebo nasycená (CNIII) vodou z předcházejících deštư. Poskytovatelem dat o nasycenosti území je ČHMÚ. Hodnoty CNII se stanovují podle tabulky 1 a 2, hodnoty CNI a CNIII se stanovují prepočtem z CNII podle rovnic (1) a (2) podle [11]. Ukazuje se, že při vyšších hodnotách CNII (od CN > 50) v kombinaci se suchým stavem nasycení povodí vycházejí hodnoty maximální retence velmi vysoké. Proto se doporučuje přepočet na stav CNI pro klimatické podmínky v České republice nepoužívat [8].

$$
C N_{1}=\frac{4,2 \cdot C N_{\|}}{10-0,058 \cdot C N_{\|}}
$$

$$
C N_{\text {III }}=\frac{23 \cdot C N_{11}}{10+0,13 \cdot C N_{11}}
$$

\section{VÝPOČET VÝŠKY PŘÍMÉHO ODTOKU}

Výpočet výšky prímého odtoku, respektive objemu prímého odtoku, se provádí pomocí empirických rovnic stanovených z dlouhodobého výzkumu. Rovnice (3) slouží ke stanovení maximální potenciální retence $A(\mathrm{~mm})$, která je pouze funkcí čísel CN (-), respektive CNII. Výpočet probíhá odděleně pro návrhové stavy před a po návrzích opatření. 


$$
A=25,4 \cdot\left(\frac{1000}{C N}-10\right)
$$

Je-li srážkový úhrn HS (mm) větší než hodnota počáteční ztráty, která má hodnotu stanovenou výzkumy 20 \% maximální potenciální retence $A$, provede se výpočet výšky prímého odtoku $H_{0}(\mathrm{~mm})$ podle rovnice (4). $\vee$ opačném prípadě je vypočtený odtok nulový. Výpočet probíhá odděleně pro scénáře s dobou opakování 20, 100 a 200 let a návrhové stavy před a po návrzích opatření

$$
H_{0}=\frac{(H s-0,2 \cdot A)^{2}}{H s+0,8 \cdot A}
$$

Objem prímého odtoku Oph $\left(\mathrm{m}^{3}\right)$ se pro konkrétní povodí stanoví pomocí rovnice (5), kde vstupy jsou výška prímého odtoku $H_{0}(\mathrm{~mm})$ a plocha povodí $P p\left(\mathrm{~km}^{2}\right)$. Výpočet probíhá odděleně pro scénáře s dobou opakování 20, 100 a 200 let a návrhové stavy před a po návrzích opatření.

$$
\mathrm{Oph}=1000 \cdot \mathrm{Ho} \cdot \mathrm{Pp}
$$

Výpočet maximální potenciální retence, výšky prímého odtoku a objemu přímého odtoku byl proveden pomocí softwaru ArcGIS 10.0. Před vlastním výpočtem bylo potřeba provést prípravu vstupních dat, která spočívala ve sjednocení velikosti gridu rastru na $10 \mathrm{~m} \times 10 \mathrm{~m}$ a souřadného systému na S-JTSK. V případě výchozího rozlišení $1 \mathrm{~km} \times 1 \mathrm{~km}$ u srážkových úhrnů došlo pouze k homogennímu rozložení do gridu $10 \mathrm{~m} \times 10 \mathrm{~m}$. Výpočty rovnic (4) a (5) pro oba návrhové stavy (před a po návrzích) a tři doby opakování (20, 100 a 200 let) probíhaly v Raster calculatoru. Pro stanovení objemu prímého odtoku Oph bylo potřeba znát plochy povodí IV. raádu Pp. Povodí IV. řádu bylo zvoleno proto, že metoda CN křivek má omezenou použitelnost pro velká území. Plochy Pp byly získány z vektorové vrstvy rozvodnic IV. rádu pro Českou republiku. Pro stanovení průměrných hodnot výšek odtoku $H_{0}$ pro jednotlivá povodí IV. rádu byla využita funkce "Zonal statistic as table". Hodnoty $P p$ a $H_{0}$ byly vloženy do programu MS Excel a pomocí rovnice (5) se stanovil objem odtoku Oph. Byly vypočitány změny odtokových poměrů, viz kapitolu Výsledky analýz.

\section{NAVRHOVANÁ OPATŘENÍ}

Snížení odtoku z povodí po prívalových srážkách souvisí se snahou omezit erozní činnost deště. Po dopadu kapky deště na povrch dojde k prvotnímu narušení krycí vrstvy půdy. Při delším účinku deště a nedostatečném vsakovaní dochází k odtoku vody z místa dopadu kapky. Odtok je nejdřive plošný, ale po několika metrech přechází v soustředěný odtok vody, který má již dostatek energie k vytvoření erozní rýhy. Ta se v průběhu deště zahlubuje a odnos půdy se urychluje. Cílem opatření je zmenšit a zpomalit nebo zastavit množství suspenze vody a půdy, která odtéká po svazích.

$U$ horních povodí není vzhledem k rychlému průběhu povodní prostor pro operativní řízení. Proto je potřeba se na prívalové srážky vhodně zvoleným souborem opatření připravit. Preferovaným řešením je změna odtokových poměrů. Ta nemusí zahrnovat jen nákladné investice do opatření, jakými jsou komplexní pozemkové úpravy, stavby akumulačních prostorů nebo protipovodňová opatření v intravilánech obcí. Lze navrhnout také nestrukturální organizační opatření, která se dají rozdělit do dvou kategorií: vyloučení pěstování erozně nebezpečných plodin (VENP) a používání protierozních agrotechnologií. Mezi strukturální opatření se řadí záchytné průlehy a příkopy, protierozní meze, ochranná zatravnění, zasakovací pásy, ochranné pásy podél vodních toků, stabilizace drah soustředěného odtoku, stavby vodních nádrží a ochranných nádrží a vymezení oblastí pro rízený rozliv do inundace. Přehled navrhovaných ideových opatření s hodnotami čísel odtokových křivek pro střední nasycení CNII a čtyři skupiny hydrologických skupin půd jsou uvedeny v tabulce 2. Jejich rozložení v území je uvedeno na mapovém portálu „Voda v krajině” [1].

\begin{tabular}{|c|c|c|c|c|}
\hline \multirow[t]{2}{*}{ Navrhovaná opatření } & \multicolumn{4}{|c|}{ HSP } \\
\hline & A & B & C & D \\
\hline záchytný průleh & 49 & 69 & 79 & 84 \\
\hline protierozní mez & 49 & 69 & 79 & 84 \\
\hline VENP & 63 & 75 & 83 & 87 \\
\hline protierozní agrotechnologie - širokořádkové kultury & 64 & 74 & 81 & 85 \\
\hline VENP a protierozní agrotechnologie & 60 & 72 & 80 & 83 \\
\hline plošné trvalé travní porosty (TTP) & 49 & 69 & 79 & 84 \\
\hline stabilizace dráhy soustředěného odtoku & 39 & 61 & 74 & 80 \\
\hline zasakovací pás & 39 & 61 & 74 & 80 \\
\hline ochranný pás podél toku & 49 & 69 & 79 & 84 \\
\hline zatravnění na speciálních kulturách & 49 & 69 & 79 & 84 \\
\hline lesnicko pěstební opatření & 30 & 55 & 70 & 77 \\
\hline ř́zená inundace - zóna rozlivu & 49 & 69 & 79 & 84 \\
\hline
\end{tabular}

Tabulka2. Hodnoty CNII pro jednotlivá navrhovaná opatření a hydrologickéskupiny pưd Table 2. CNII values for individual designed protection and hydrological types of soils

Strukturální opatření, která řeší změnu odtokových poměrů technickými opatřeními, jsou náročná na prípravu a finanční prostředky. Př́pravné práce před realizací návrhů opatření reší vlastní technický návrh podle platných norem, návaznost na stávající stavby, zákonné potřeby a požadavky vlastníků okolních a dotčených pozemků. Stavbou se nesmí zhoršit odtokové podmínky v jiných místech povodí. Jedním z nejsložitějších úkolů přípravy je výkup pozemků pro vlastní navrhované stavby.

\section{Změna odtokových poměrů}

Každá výše uvedená změna s sebou přináší snižení hodnot čísel CN, zvýšení maximální potenciální retence, snižení výšky odtoku a snížení objemu odtoku. Objem odtoku se výrazně projeví v případě, že se změna využití území aplikuje na větším území. Nejlepších výsledků je dosaženo při změně využití pozemku z orné půdy na les [8]. Méně účinná, ale stále prínosná je změna z orné půdy na prirozené louky nebo změny luk a pastvin na les. Změna přirozených luk na lesy má z uvažovaných možností změn nejmenší efekt. Pozitivní efekt těchto změn se bude dále zvětšovat s rostoucí výškou srážkového úhrnu. Zmenšení výšky odtoku je způsobeno pomalejším odtokem a tím i větším časem na vsáknutí (infiltrace vody) do půdy. Je nutné podotknout, že zvětšení vsaku má pozitivní vliv na aktuální povodňovou událost z přivalových srážek, ovšem na roční bilanci stavu podzemních vod se změna využití pozemku projeví jen minimálně, nebot infiltrace je krátkodobá. 


\section{VÝSLEDKY ANALÝZ}

Znalost odtokových podmínek a potřeb ochrany území byla v rámci projektu Strategie podkladem k návrhưm vhodných opatření, prípadně celého komplexu opatření v plochách povodí, viz [1]. Na základě porovnání objemů přímého odtoku pro současný stav využití území s objemy prímého odtoku pro návrhový stav s protierozními opatřeními v jednotlivých povodích Ize stanovit, jaký mají navrhovaná ideová opatření vliv na změnu odtokových poměrů. Výsledky řešení byly využity pro hodnocení účinnosti navržených opatření na zemědělské půdě.

Změny odtokových poměrů byly vyhodnoceny pro prípad CNII s návrhovými 24hodinovými srážkami se třemi dobami opakování (20, 100 a 200 let). Pro jednotlivá povodí IV. rádu bylo podle rovnice (6) provedeno srovnání relativních odchylek výšek odtoku $\Delta r(\%)$ současného $H_{0, \text { soucasnost }}$ a návrhového stavu $H_{\text {O,navrh }}$ území pro jednotlivé doby opakování, viz obr. 2. Z grafu je patrné, že na velké části povodí IV. řádu nedošlo k žádným návrhům $(\Delta r=0)$. Většina relativních odchylek je menších než cca 50 \%. Se zvětšujícími se hodnotami relativních odchylek klesá jejich četnost rychleji u větších dob opakování. To platí i u absolutních odchylek na obr. 3. Se zvětšujícími se hodnotami $\Delta r$ je pokles četností $\checkmark$ případě doby opakování $N=20$ přibližně lineární, u dob opakování $N=100$ a $N=200$ má exponenciální průběh. Rozložení hodnot $\Delta r$ je výrazně jiné pro dobu opakování $\mathrm{N}=20$ než u dob opakování $\mathrm{N}=100$ a $\mathrm{N}=200$.

$$
\Delta r=\frac{H_{0, \text { soucasnost }}-H_{0, \text { navrh }}}{H_{0, \text { soucasnost }}} \cdot 100
$$

Dále bylo pro jednotlivá povodí IV. rádu provedeno podle rovnice (7) srovnání absolutních odchylek výšek odtoku $\Delta a(\mathrm{~mm})$ současného $H_{\text {osoucasnost }}$ a návrhového stavu $H_{\text {onavrh }}$ území pro jednotlivé doby opakování, viz obr. 3 . Z grafu je patrné, že většina absolutních odchylek je menších než cca $15 \mathrm{~mm}$. Účinek relativního snižení výšky odtoku se snižuje se zvětšující se dobou opakování.

$$
\Delta a=\left|H_{O, \text { soucasnost }}-H_{O, \text { navrh }}\right|
$$

Poslední analýza se zabývala srovnáním absolutních odchylek (rozdílů) objemů odtoku $\triangle$ Oph $\left(\mathrm{m}^{3}\right)$ současného Oph soucasnost a návrhového stavu Oph $_{\text {navrh }}$ území podle rovnice (8) pro jednotlivá povodí IV. rádu a pro jednotlivé doby opakování, viz obr. 4. Z grafu je patrné, že většina odchylek je menších než cca 300 tisíc $\mathrm{m}^{3} \mathrm{v}$ jednom povodí. Většina povodí IV. rádu je schopna zachytit objem vody v rádu desítek tisíc $\mathrm{m}^{3}$.

$$
\Delta O p h=\left|O p h_{\text {soucasnost }}-O p h_{\text {navrh }}\right|
$$

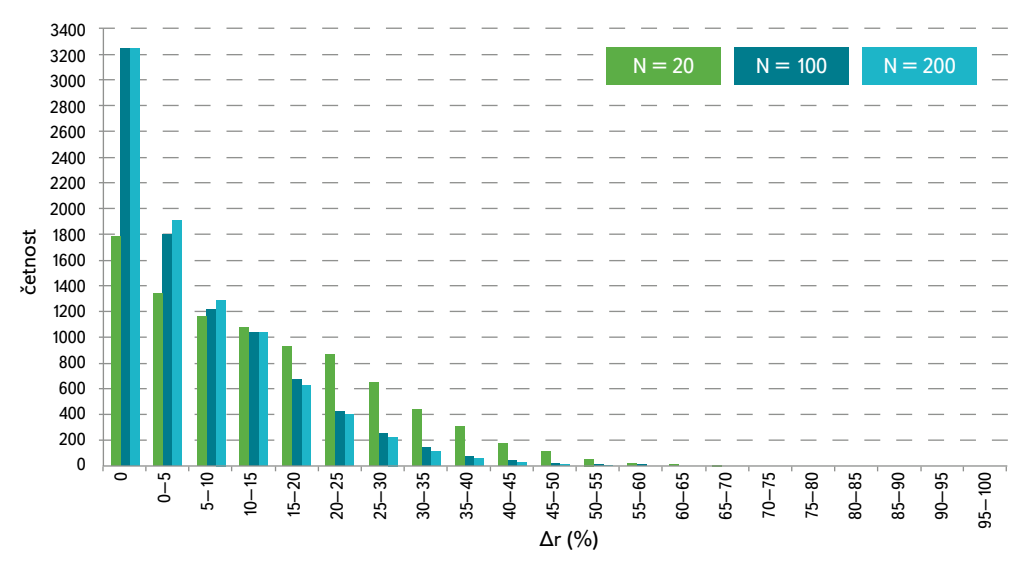

Obr. 2. Rozložení četnosti relativních odchylek výšek odtoku před a po návrzích Fig. 2. Histogram of relative deviations of actual runoff for states before and after proposals

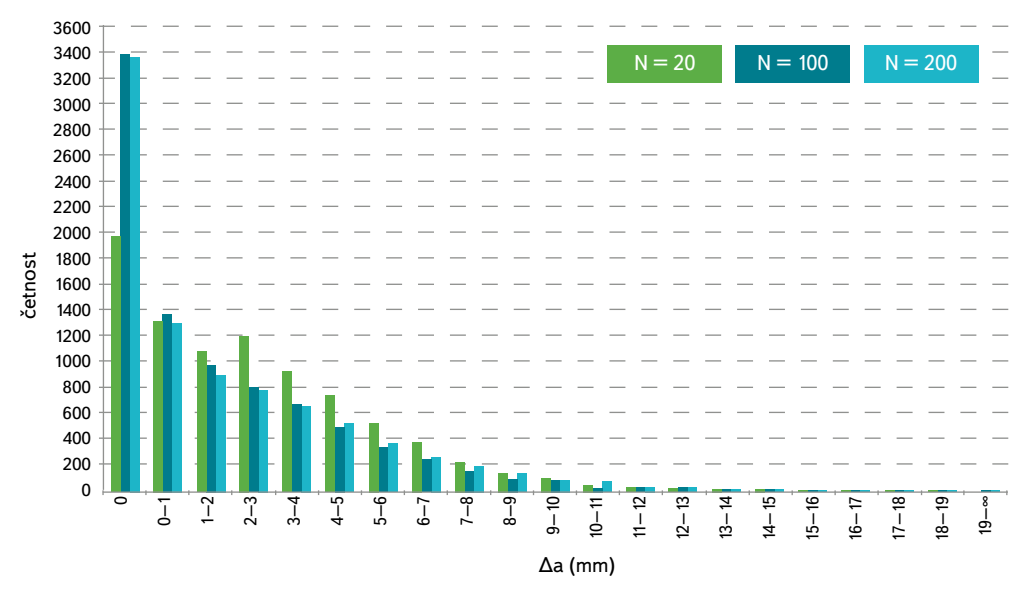

Obr. 3. Rozložení četnosti absolutních odchylek výšek odtoku před a po návrzích Fig. 3. Histogram of absolute deviations of actual runoff for states before and after proposals

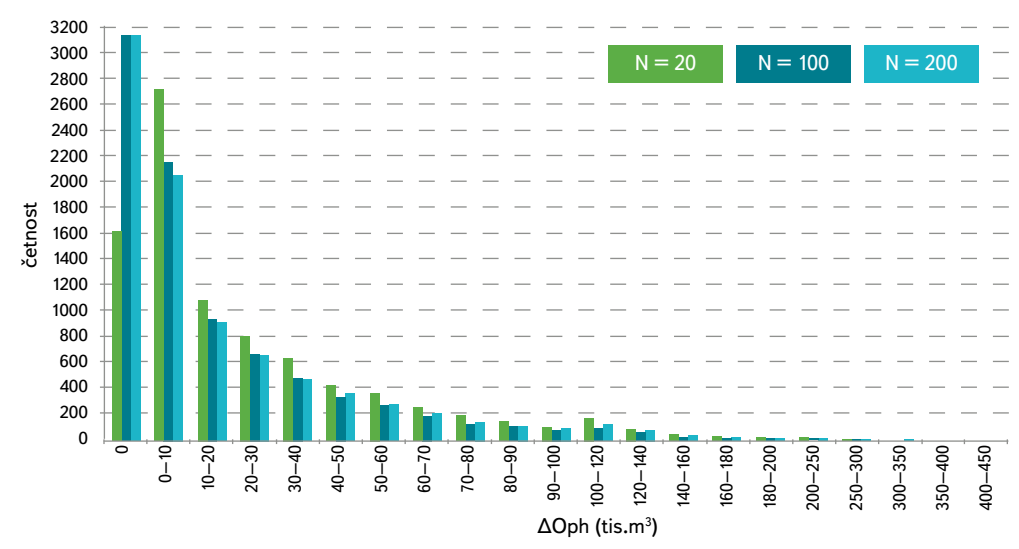

Obr. 4. Rozložení četnosti absolutních odchylek objemu odtoku pred a po návrzích Fig. 4. Histogram of absolute deviations of runoff volume for states before and after proposals 


\section{ZÁVĚR A DISKUSE}

Dílčím úkolem projektu Strategie bylo stanovení odtokových poměrů v povodích IV. rádu pro území celé České republiky. Vyjádřit odtokové vlastnosti území pomocí automatizovaného postupu v prostředí GIS při znalosti návrhových srážek, typu povrchu a způsobu jeho využití umožňuje metoda čísel odtokových křivek (CN). Přestože má metoda svá omezení a původně byla odvozena pro malá nesvažitá povodí, používá se v podmínkách ČR i pro větší a svažitější povodí. Výpočet odtoku z celého povodí byl proveden pro současný stav využití území. V některých povodích byla v teoretické rovině na zemědělských pozemcích navržena protierozní a protipovodňová opatření, viz [1]. Cílem návrhů bylo zvýšit zasakovací schopnost krajiny, zpomalit a snížit odtok z území během prívalové epizody. Návrhy strukturálních a nestrukturálních opatření na zemědělské půdě, na tocích a $v$ nivě včetně zastavěného území $a v$ podobě nových retenčních prostor jsou koncipovány tak, aby došlo ke změně odtokových poměrů. Podle zkušeností lze očekávat, že realizovatelnost těchto opatření bude úzce svázaná s prováděním komplexních pozemkových úprav. Po návrzích došlo k opětovnému výpočtu odtoku z povodí, v tomto prípadě na nové vrstvě CN zohledňující navrhovaná opatření v území. Následně došlo k vyhodnocení změn odtokových poměrů a srovnání charakteristik odtoku pro tři návrhové srážky (24hodinový déšt s dobou opakování 20, 100 a 200 let).

Podle doby opakování deště nedošlo na 20 až 36 \% povodí IV. řádu (z celkových 8958 povodí) ke změnám odtokových poměrů. To je způsobeno tím, že v povodích nebyla navržena žádná opatření nebo srážkový úhrn nepřesáhl očekávanou počáteční infiltraci. Na většině území České republiky došlo ke snížení výšky prímého odtoku $H_{0}$. Relativní snížení výšky odtoku se pohybuje obvykle do $50 \%$. V absolutních hodnotách dochází po návrzích ke snížení výšky odtoku do cca $15 \mathrm{~mm}$, většinou ale jen do $10 \mathrm{~mm}$. Vzhledem k tomu, že povodí mají různou rozlohu, je vhodnější a více vypovídající charakteristikou objem odtoku z povodí. Většina povodí IV. rádu je schopna pomocí návrhových opatření pojmout navíc objem vody v rádu desítek tisíc $\mathrm{m}^{3}$, výjimečně až stovek tisíc $\mathrm{m}^{3}$. Celková absolutní změna objemu za celou ČR je v prípadě doby opakování 20 let 238 mil. m³ doby opakování 100 let 181 mil. m³ a doby opakování 200 let 198 mil. m³, což je pro představu trojnásobek až čtyřnásobek celého retenčního prostoru Orlické přehrady.

$\checkmark$ mnohých případech je změna v odtokových poměrech nepatrná a někdy dokonce zanedbatelná. $V$ takových prípadech nemá valný význam navrhovat drahá a organizačně náročná opatření v ploše povodí. K tomuto zjištěnému faktu bylo $v$ dalších fázích řešení projektu Strategie přihlíženo.

V mapové aplikaci [1] v sekci „Erozní ohrožení zemědělské půdy“ Ize v horním pravém rohu zobrazit seznam vrstev. V části „erozni_ohrozeni_zem_pudy“ Ize zobrazovat zvlášt navrhované retenční nádrže a ostatní technická i netechnická opatření. Lze zobrazit návrhy na změny pěstování kultur, osevních postupů nebo technických protierozních opatření. V části „analyticke_rastry“ Ize zobrazovat rozložení CNII nebo erozní smyv prèed návrhem opatření, prípadně zobrazit sklonitost terénu.

\section{Poděkování}

Článek vznikl na základě výsledků projektu Strategie ochrany pred negativními dopady povodni a erozními jevy prírodě blízkými opatřeními v České republice, který byl řešen v letech 2014 a 2015 a který byl financován prostředky OPŽP. Za spolupráci na řešení projektu děkuji Ing. Ladislavu Kašpárkovi, CSc., a za korekci př́spěvku Ing. Karlu Drbalovi, Ph.D.

\section{Literatura}

[1] OPŽP. Voda v krajině. Dostupné z: http://www.vodavkrajine.cz/mapove-kompozice

[2] EBRAHIMIAN, M.M., NURUDDIN, A.A.B., SOOM, M.A.B.M., and SOOD, A.M. Application of NRCS Curve number method for runoff estimation in a mountainous watershed. Caspian Journal of Environmental Sciences, 10(1), 2012, p. 103-114.

[3] ŘEDINOVÁ, J., PAVLÁSEK, J. a MÁCA, P. Hydrologie. Návody ke cvičením. Praha: ČZU, 2009, 79 s.

[4] DOSTÁL, T., DAVID, D., VRÁNA, K. a NOVÁKOVÁ, H. Studie odtokových poměrư v povodí Weisseritz část I. Mapa zdrojových ploch povrchového odtoku. Praha: ČVUT, 2006, $126 \mathrm{~s}$

[5] JANEČEK, M. Ochrana zemědělské pưdy préd erozí. Praha: ČZU, 2012, $113 \mathrm{~s}$

[6] DUMBROVSKÝ, M. Úprava odtokových poměrů v povodí. Modul M01. Studijní opory pro studijn programy s kombinovanou formou studia. Brno: VUT, 2007, s. 46.

[7] CRONSHEY, R. Urban hydrology for small watersheds. US Dept. of Agriculture, Soil Conservation Service, Engineering Division, 1986, $164 \mathrm{p}$

[8] KAŠPÁREK, L. a PELÁKOVÁ, M. Analýza citlivosti změn objemu přímého odtoku a infiltrace do půdy při předpokládaných změnách užívání pozemků. VTEl 5/2014, 2014, s. 8-12, př́loha Vodního hospodárstvíč. 10/2014.

[9] Ministerstvo zemědělství. LPIS. Dostupné z: http://eagri.cz/public/app/lpisext/lpis/verejny/

[10] CENIA. CORINE Land Cover. Dostupné z: http://geoportal.cenia.cz

[11] CHOW, V.T., MAIDMENT, D.R., and MAYS, L.W. Applied hydrology. New York: McGraw-Hill, 1988, 572 p.

\section{Autor}

Ing. Lukáš Smelík, Ph.D.

凶lukas_smelik@vuv.cz

Výzkumný ústav vodohospodářský T. G. Masaryka, v. v. i., pobočka Brno

Př́spěvek prošel lektorským řizením.

\section{ANALYSIS OF CHANGES IN RUNOFF FOR CZECH REPUBLIC}

\section{SMELIK, L.}

TGM Water Research Institute, p. r. i., Brno branch

Keywords: rainfall - CN curves - runoff - erosion erosion protection - flood protection

One part of the project "Strategy for protection against negative impacts of floods and erosion phenomena by nature-friendly measures in the Czech Republic" was assessment of actual runoff conditions in the Czech Republic by runoff curve number method. Erosion protection and flood protection measures were designed at areas of chosen catchments, where high runoff and low retention were determined. Following from previous experiences, the efficient, economically acceptable and enforceable typified protection measures were designed. Effect of the designed protection was assessed by computation by means of the runoff curve number method at the whole area of the Czech Republic. The differences in runoff between actual state of territory and state with designed protection on territory were analysed. Territory was discretized on catchment area of the $4^{\text {th }}$ order. Analyses were made in ArcGIS software. 